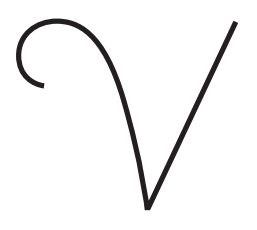

\title{
Komenský v Rusku: O tradicích a perspektivách rozvoje ruské komeniologie ${ }^{1}$
}

Světlana Markovna

\section{Marčukováa}

a Výzkumné pedagogické centrum

J. A. Komenského, Petrohrad,

Ruská federace

marchukova@bk.ru

DOI 10.15240/tul/006/2021-2-010

\section{Recepce Komenského díla v ruské literatuře}

Historie tištěných překladů děl Jana Amose Komenského v Rusku začíná v druhé polovině 18. století. První překlad učebnice Orbis pictus (s názvem Orbis visibilis) označující autora a titul knihy v originále byl původně publikován při Carské moskevské univerzi-

tě ve dvou edicích $-\mathrm{v}$ roce 1768 a 1788 . Obě publikace postrádaly předmluvu a ilustrace Komenského. J. A. Komenský se zabýval nejen smyslově vnímatelnými objekty, ale i řadou abstraktních pojmů (duše, spravedlnost, lidskost, věda, stát atd.) s využitím jejich symbolů nebo alegorických obrazů.

V roce 1788 bylo v Petrohradě publikováno třetí vydání učebnice s názvem Vesmírná podívaná v latině, ruštině a němčině, kde z celkových 150 kreseb bylo 80 kreseb Komenského. Text publikace, která byla první dětskou encyklopedií, byl podroben podstatné redukci. Pedagogický odkaz J. A. Komenského ovlivnil jak ruské pedagogické myšlení, tak i jednotlivá díla ruských pedagogů.

Do 19. století byl v ruské pedagogice Komenský vnímán jako didaktik. Publikace Svět vobrazech nebo Vesmírná podivaná (1808 a 1822) byly vydány dvakrát. V období od 2. poloviny 19. do počátku 20. století se šířilo komplexní studium Komenského odkazu spojené s utvářením se ruské pedagogiky jako vědecké disciplíny. Velkého ohlasu se dočkala 
dvě výročí - 200. výročí smrti Komenského (1870) a 300. výročí jeho narození (1892). Během těchto let se obnovil zájem o jeho odkaz, vznikají muzea, knihovny a pedagogické společnosti, které nesou Komenského jméno. V roce 1869 byl vydán překlad životopisné eseje o Komenském od českého historika Františka Palackého.

VnímáníJana Amose Komenského jako zakladatele evropské pedagogiky novověku je tradičně spojováno s vědeckou a vzdělávací činností S. I. Miropolského a s jeho zásadním článkem Jan Amos Komenský a jeho význam v pedagogice publikovaným v Časopise Ministerstva národního vzdělávání (1871). Pod redakcí S. I. Miropolského byl v Rusku v letech 1875-77 publikován překlad Velké didaktiky.

V roce 1904 byl přeložen z češtiny vrchol literárního díla Komenského, Labyrint světa a ráj srdce. V roce 1915 vyšla monografie Pavla Petroviče Blonského Jan Amos Komenský, která neztrácí svůj význam ani v naší době. Jméno J. A. Komenského má pevné místo v ruských učebnicích pedagogiky a dějin pedagogiky. Centrem pro studium jeho odkazu se stala činnost oddělení Komenského, jednoho z oddělení Petrohradského pedagogického muzea Hlavního ředitelství vojenských škol. Toto muzeum bylo na přelomu 19. a 20. století hlavním vědecko-pedagogickým centrem země. Zde vznikaly nové překlady Velké didaktiky (1893), Informatoria školy mateřské, Zákonů školy dobře uspořádané (1893). Byly publikovány vybrané práce Komenského (1892-1897) včetně jeho pedagogických děl (Moskva, 1893-1894).

\section{Obraz Komenského v ruské komeniologii a pedagogice}

Na konci 19. století byl Komenský jen zřídka uváděn v historickém a pedagogickém výzkumu zaměřeném na období raného novověku. V první čtvrtině 20. století se na Komenského skoro nikdo neodkazoval. Jeho učení bylo považováno za „zastaralé“ a nebylo studováno do hloubky. Vliv tohoto období na národní komeniologii je pocitován i nyní a odráží mechanistické pojetí integrity a dưraz na instrumentální koncepci v pedagogickém myšlení (vnější determinace růstu-výchovy lidské bytosti), jak je zřejmé již od osvícenství. Jednota pansofických a didaktických esejí Komenského, pansofie a pampaedie, v tomto pojetí zůstává neodhalena. 
Základní pedagogické myšlenky J. A. Komenského, které odrážejí pansofickou orientaci jeho odkazu, proto nebyly shledávány jako zásadní podklad Komenského didaktických snah - souboru praktických rad o organizaci systému výuky. Tato situace však měla i objektivní důvod: mělo se za to, že hlavní pansofické dílo Komenského Obecná porada o nápravě věcí lidských bylo nenávratně ztraceno. Jeho rukopis nalezl D. I. Čiževskij v roce 1934, publikoval jej v originálním latinském jazyce v roce 1966 a ve druhé polovině 20. století přeložil do moderních jazyků. To byl hlavní objev domácí a zahraniční komeniologie 20. století a na dlouhou dobu určil priority jejího rozvoje.

V roce 1953 byla publikována monografie A. A. Krasnovského Jan Amos Komenský, ve které autor klade dưraz na sociálně-filosofický aspekt dědictví Komenského. V roce 1959 byl vydán překlad německé monografie R. Alta Pokrokový charakter Komenského pedagogiky.

Další proces porozumění tvưrčí práce Komenského v ruské komeniologii souvisí především s následujícími událostmi:

1) latinské vydáni Obecné porady pro nápravu věcílidských (1966);

Komeniologické práce tohoto období neodráží ani tak zájem o didaktiku Komenského, ale spíše o jeho základní pedagogické myšlenky. V roce 1970 vyšla monografie D. O. Lordkipanidzeho Jan Amos Komenský, ve které je jeho odkaz prezentován v souladu s mezinárodními komeniologickými tendencemi.

2) vydání společné dvoudílné sovětsko-československé publikace Vybraná díla J. A. Komenského v ruštině s rozsáhlými komentáři (1982); Vydání dvoudílného svazku znamenalo začátek komplexního interdisciplinárního př́stupu k odkazu Komenského. Byl to pokus o syntetický, holistický pohled na Komenského nejen jako na velkého učitele, ale také jako na velkého sociálního myslitele a filosofa novověku. V roce 1982 vychází monografie G. N. Džibladzeho Filosofie Komenského. 3) série komeniologických publikacív souvislosti se 400. výročím narození J. A. Komenského (1992);

UNESCO vyhlásilo rok 1992 rokem Komenského. Při přípravě na jubilejní rok byl publikován soupis jeho prací. V roce 1990 se konalo v Moskvě mezinárodní sympozium Člověk, kultura, společnost v pojetí J. A. Komenského. Bylo poukázáno na to, že Komenského dílo nabývá 
na významu teprve v aktuální době. Za nejvyšší dosažení jeho pedagogického odkazu se však nepovažuje již didaktika, ale pansofie, která je syntézou a jednotou všech existujících znalostí o světě, podmínkou pro vytvoření holistického světového pohledu.

\section{Aktuální komeniologické diskuse v Ruské federaci}

Ruští filosofové, pedagogové a psychologové si jsou dnes vědomi nedostatečného pochopení odkazu Komenského a pedagogického potenciálu jeho děl. Různí autoři věnují pozornost podobnosti doby Komenského se současností. Dochází k přehodnocení komeniologie sovětského období. V březnu 1992 proběhlo zasedání Vědecké rady pro problematiku dějin školství a pedagogiky na Ruské akademii vzdělávání na téma Teoretický odkaz Komenského a současné problémy pedagogiky. Mezinárodní vědecké a praktické konference se konaly v Čeboksarech (Komenský a moderni škola) a v Čeljabinsku (Komenský a současné vzděláváni: Problémy, hledání, řešeni). Významným příspěvkem k rozvoji ruské komeniologie byly práce Georgije Mělnikova a jeho průběžný vědecký výzkum. Komenského díla jsou publikována v sérii Antologie humanitní pedagogiky (1996) a Památky filosofického myšlení (1997) $\mathrm{s}$ úvodním článkem Dmitrije Čiževského.

Dvacáté první století ruské komeniologie se otevírá novým (poprvé od roku 1904) vydáním Labyrintu světa v překladu Sergeje Skorvida. V roce 2003 byla vydána Pampaedie v Ruské akademii vzdělávání s rozsáhlými komentáři. Byly publikovány monografie Světlany Marčukové Jan Amos Komenský: mužv „labyrintu světa“ (2006), Jan Amos Komenský: Pozvání k dialogu (2008), Heuristický potenciál myšlenky pansofie v pedagogickém dědictví J. A. Komenského (2013) a další monografie a články. Publikace odhalují nové filosofické a pedagogické významy zakladatele pedagogické vědy.

Od r. 2007 pořádá Výzkumné centrum pedagogiky J. A. Komenského při německém gymnáziu Peterschule v Petrohradě mezinárodní komeniologické semináře a vědecko-praktické konference. V roce 2015 byla v Petrohradě na základě práce tohoto centra vytvořena sekce komeniologie jako stálé uskupení Petrohradské vědecké společnosti. Od samého počátku své činnosti tato komeniologická výzkumná centra 
aktivně spolupracují s Národním pedagogickým muzeem a knihovnou J. A. Komenského v Praze.

V roce 2015 vydala Ruská akademie vzdělávání výsledky první části studie zabývající se učebnicemi v 17. století. V této studii je věnována velká pozornost učebnicím Komenského. V roce 2017 se v Moskvě a Petrohradu konaly čtyři konference věnované 425 . výročí narození Komenského, v dubnu 2018 se na výroční konferenci Petrohradské vědecké společnosti uskutečnil seminář v sekci komeniologie s komeniologickým příspěvkem Markéty Pánkové, ředitelky Národního pedagogického muzea a knihovny J. A. Komenského v Praze.

V roce 2018 byl publikován překlad Komenského eseje Fyzika v ruském jazyce v moskevském časopise Intelektuální tradice s úvodním článkem Světlany Marčukové. Moderní ruská komeniologie je charakterizována snahou pochopit filosofickou a sociální orientaci Komenského odkazu v kontextu dějin kultury a vědy. Tyto studie potvrzují aktuálnost, heuristický potenciál jeho děl, nastiňují vyhlídky rozvoje ruské komeniologie jako širokého interdisciplinárního vědeckého směru v oblasti pedagogické teorie a praxe. 